\title{
The Pharmacognostic Profile and Biological Potential of Traditional Medicinal Shrub Hibiscus hiritus L.
}

\author{
PADMAJA KOTA ${ }^{1 *}$, G. SERU, J. PANDA ${ }^{1}$, P. K. SAHU ${ }^{1}$ AND MARY SULAKSHANA PALLA ${ }^{1}$ \\ Department of Pharmacognosy, GITAM Institute of Pharmacy, Gandhinagar, Rushikonda, Visakhapatnam-530 045, \\ ${ }^{1}$ Department of Pharmacognosy, Raghu College of Pharmacy, Dakamarri, Bheemunipatnam (M), Visakhapatnam-531 162, \\ India
}

Kotai et al.: Pharmacognostic Profile and Biological Potential of Hibiscus hiritus

\begin{abstract}
The proposed study has largely focused on two distinct lines of investigation. In the first approach, efforts have been made to evaluate macroscopic and microscopic pharmacognostic characteristics of Hibiscus hiritus L. In the second approach, the pharmacological potential of the whole plant extract was explored for in vitro antioxidant, antimicrobial and in vivo antiinflammatory activity. The extract and dry powdered plant material were screened for phytochemical constituents and other physiochemical parameters. Various microscopic characteristics of fresh leaves and stem of the plant (paradermal and T.S) were extensively evaluated. Methanol extract of the whole plant was used for pharmacological screening. Antioxidant potential of the extract was evaluated using the 1,1-diphenyl-2-picryl-hydrazil and hydroxyl radical scavenging assay using ascorbic acid as the standard. Antimicrobial property was evaluated using cup plate method against Staphylococcus aureus, Bacillus subtilis, Proteus vulgaris, Escherichia coli, Aspergillus niger and Candida albicans. Antiinflammatory potential was evaluated in the rat carrageenan-induced paw edema model. The $\mathrm{IC}_{50}$ values obtained in the antioxidant assay were, $42 \pm 0.06$ and $2.8 \pm 1.64 \%$ in the 1,1-diphenyl-2-picryl-hydrazil and hydroxyl radical scavenging assay, respectively. Inhibitory activity was observed against Staphylococcus aureus $(14 \pm 0.15 \mathrm{~mm})$, Bacillus subtilis $(14 \pm 0.13 \mathrm{~mm})$ and Escherichia coli $(14 \pm 0.16 \mathrm{~mm})$. The study also revealed significant and dose-dependent antiinflammatory activity in the carrageenan-induced rat paw edema model. The present study explored the pharmacognostic features and the pharmacological potential of Hibiscus hiritus to provide evidence for the traditional therapeutic use of the plant as an antibacterial, antioxidant and antiinflammatory agent.
\end{abstract}

Key words: Antioxidant, antimicrobial, antiinflammatory, Hibiscus hiritus, pharmacognostic profile

The biological potential of medicinal plants has been recognized since time immemorial. Even today, most population in many developing countries like India and China depend on herbal remedies to cure infectious diseases as an alternative to allopathy. Screening of bioactive natural compounds hence has been of great interest by researchers. Morphoanatomical studies and pharmacological evaluation have been proved as essential tools in routine quality control of new medicinal plants. Choice of these herbal screening tools has been adding valuable scientific information to establish rational relationship between chemical, biological and therapeutical activities of traditional plants $^{[1]}$. Moreover, ethnomedical data of herbs not only provide a new direction for drug discovery, but also offer significant socio-economic benefits ${ }^{[1-3]}$.

*Address for correspondence

E-mail: pharma.padmaja@gmail.com

January-February 2020
In this purview, the present study was designed to explore the pharmacognostic and pharmacological characteristics of Hibiscus hiritus (family: Malavaceae), commonly known as lesser mallow. It is a small tropical ornamental subshrub, traditionally used as a potent bactericidal, antioxidant and antiinflammatory agent.

The plant extract is a chief ingredient (arkapushpi) in Siddha and Ayurvedic preparation swarnaprashan, which is beneficial for good body growth, strength,

\footnotetext{
This is an open access article distributed under the terms of the Creative Commons Attribution-NonCommercial-ShareAlike 3.0 License, which allows others to remix, tweak, and build upon the work non-commercially, as long as the author is credited and the new creations are licensed under the identical terms
}

Accepted 12 December 2019

Revised 25 September 2019

Received 14 May 2019

Indian J Pharm Sci 2020;82(1):139-148 
intelligence, tones skin colour and immunity for prevention of diseases in young children ${ }^{[4]}$.

In spite of significant traditional uses, $H$. hiritus is still unknown to scientific society. The present study was aimed to explore the pharmacognostic features and the pharmacological potential of $H$. hiritus with speculation on the traditional therapeutic promise of the plant as a potent antibacterial, antioxidant and antiinflammatory agent. The scope of the study remained novel to acquire reliable ethanomedical data for developing more effective and less toxic medicines.

\section{MATERIAL AND METHODS}

Indomethacin was a kind gift from Recon Pharma (Bangalore, India). L-ascorbic acid, thiobarbituric acid, 1,1-diphenyl-2-picryl-hydrazil (DPPH), deoxyribose were procured from CDH Pvt. Ltd., New Delhi, India. Carrageenan (Sigma Chemicals, St. Louis, MO, USA), disodium hydrogen phosphate, sodium dihydrogen phosphate, potassium dihydrogen phosphate, hydrogen peroxide (Yarrow Chem, Mumbai, India); phloroglucinol (Merck life sciences, Mumbai, India); Jeffrey's maceration fluid, glycerol, hydrochloric acid, formalin, acetic acid, ethyl alcohol, tertiary-butyl alcohol, paraffin wax, toluidine blue-O, safranin-O and fast-green FCF, potassium iodide, $\mathrm{NaOH}$, trichloroacetic acid, methanol, ferric chloride (Thermo Fisher Scientific, Mumbai, India) were used.

\section{Collection and characterization of plant materials:}

The plants of $H$. hiritus were collected from Agroforestry, Boyapalem, Visakhapatnam, in March 2017, identified and authenticated at the Botanical survey of India, Hyderabad, Telangana. A voucher specimen (BSI/DRC/2016-17/Tech/969) was deposited at the herbarium of the Botanical Survey of India, Hyderabad.

\section{Macroscopic characterization:}

Various macroscopic characters of the fresh whole plant of $H$. hiritus such as the height of the plant, characters of leaf, flower, stem, root and seeds were recorded. This macroscopic evaluation of the plant was studied according to the methods described in the textbook of pharmacognosy ${ }^{[5]}$.

\section{Microscopic characterization:}

Healthy plants were chosen for excision of various parts for the proposed study. Following excision, the specimens were fixed in FAA solution containing $5 \mathrm{ml}$ formalin, $5 \mathrm{ml}$ acetic acid and $90 \mathrm{ml}$ of $70 \%$ ethyl alcohol. After $24 \mathrm{~h}$ of fixing, the specimens were dehydrated with graded series of tertiary butyl alcohol (TBA) as per the schedule given in previous studies ${ }^{[6]}$. Further, the specimens were subjected to infiltration by gradual addition of paraffin wax until super saturation of TBA solution is attained. The specimens were cast into paraffin blocks. The paraffin embedded specimens were sectioned with the help of a Rotary Microtome (Bluefic Industrial and Scientific Technologies, Ambala, India) so as to get fine thickness of 10-12 $\mu \mathrm{m}$. Dewaxing of the sections was done using the customary procedure ${ }^{[7]}$. The sections were suitably stained with toluidine blue to render pink colour to the cellulose walls, blue to the lignified cells, dark green to suberin and violet to the mucilage $^{[8]}$.

\section{Preparation of paradermal sections:}

Paradermal sections were prepared to study the stomatal morphology, venation pattern and trichome distribution. Initially, the leaf specimens were treated with $5 \% \mathrm{NaOH}$ for clearing the chlorophyll. Optionally, epidermal peeling by partial maceration in Jeffrey's maceration fluid ${ }^{[6]}$ has also be chosen. Saffranin solution (1\%) was used for staining the specimens. After staining, the specimens were observed under Nikon Labophot-2 microscope (Wazobia Enterprise, USA) for tissue description and imaging. Bright light illumination was used for normal observations and polarized light for the study of crystals and lignified cells. Crystals and lignified cells bear birefringent property and under polarized light they appear bright against dark background. Magnifications of the figures were indicated by the scale-bars and the anatomical features were described ${ }^{[9-11]}$.

\section{Extraction of plant materials:}

Whole plants of $H$. hiritus were shed dried, powdered using a mechanical grinder and passed through sieve \# 40. For preliminary phytochemical studies, $200 \mathrm{~g}$ each of the powdered material was extracted in a Soxhlet apparatus with hexane, chloroform and methanol successively followed by drying under vacuum in a rotary evaporator (Model-R-1001-VN, ZGSIT, China). Further, approximately $1 \mathrm{~kg}$ of powdered $H$. hiritus was macerated with methanol and the menstruum was concentrated and dried in a rotator vacuum. The dried extract was used to determine various pharmacological activities. 


\section{Preliminary phytochemical and physiochemical screening:}

Extracts were subjected to standard test procedures for the presence or absence of different phytoconstituents. Physiochemical values such as the percent total ash, acid-insoluble ash, water-soluble ash and water/alcohol soluble extractives were calculated as per the Indian Pharmacopoeial procedures ${ }^{[12]}$.

\section{Test microorganisms and animals:}

Antimicrobial activity of the methanol extract was screened on Bacillus subtilis, Staphylococcus aureus (Gram-positive), Escherichia coli, Proteus vulgaris (Gram-negative) and two fungal strains Aspergillus niger and Candida albicans. Freeze-dried strains were procured from Microbial type culture collection (MTCC), IMTECH, Chandigarh, Punjab. The cultures were maintained on nutrient agar slants at $4^{\circ}$.

For antiinflammatory activity, Wistar rats of either sex (age: $12 \mathrm{w}$, weight: 200-250 g) were procured and housed under $12 \mathrm{~h}$ light-dark cycle under controlled humidity (60-70\%) and temperature $\left(24 \pm 2^{\circ}\right)$ till completion of the experiments. Prior to the experiment, rats were fed with pellet diet and provided water ad libitum. All rats were brought to the experiment room $2 \mathrm{~h}$ before the experiment and ensured that they are well accustomed with the condition. The experimental procedure and protocols were in accordance to the guidelines of the Committee for the Purpose of Control and Supervision of Experiments on Animals (CPCSEA), India. The protocols were reviewed and approved by the Institutional Animal Ethics Committee (1549/PO/Re/S/2011/CPCSEA).

\section{Antioxidant capacity:}

Antioxidant capacity is the ability of the of plant extract to terminate the peroxidation chain reaction by quenching the peroxide radicals, which is highly essential for improving the quality and stability of food products. Spectrophotometric method-based DPPH and hydroxyl radical scavenging assays were performed to determine antioxidant capacity of $H$. hiritus extract. A modified DPPH assay was conducted to evaluate free radical scavenging activity using methanol extract of H. hiritus ${ }^{[13-15]}$. Antioxidant potential of the plant extract was measured in terms of decrease in UV absorbance due to reduction of DPPH at $517 \mathrm{~nm}^{[16]}$. To $1 \mathrm{ml}$ of $0.1 \mathrm{mM}$ DPPH solution in methanol, $3 \mathrm{ml}$ of various concentrations $(5,10,15,20,25,30,35,40,45,50 \mu \mathrm{g} / \mathrm{ml})$ of test sample were added individually and kept aside for $30 \mathrm{~min}$ to complete the reaction. Absorbance of the resultant mixtures was then measured at $517 \mathrm{~nm}$ using a UV/Vis spectrophotometer (Shimadzu, UV-1601, Japan). The percent free radical scavenging was calculated using Eqn. 1, by comparing the absorbance values of the blank and test samples. Ascorbic acid was used as a reference compound. The antioxidant potential of the extract was expressed as $\mathrm{IC}_{50}$, which is the concentration (in $\mu \mathrm{g} / \mathrm{ml}$ ) of extracts required to inhibit the formation of DPPH radicals by $50 \%$. Eqn. 1: \% scavenging activity $=\left(A_{b}-\mathrm{A}_{\mathrm{t}}\right) / \mathrm{A}_{\mathrm{b}} \times 100$, where, $\mathrm{A}_{\mathrm{b}}$ is absorbance of blank and $\mathrm{A}_{\mathrm{t}}$ is absorbance of test and (or) standard.

Hydroxyl radical scavenging ${ }^{[17,18]}$ was measured based on the competition between deoxyribose and test extract for hydroxyl radicals generated by Fenton reaction $\left(\mathrm{Fe}^{3+}\right.$-ascorbate-EDTA- $\left.\mathrm{H}_{2} \mathrm{O}_{2}\right)$.The reaction mixture was prepared with $100 \mu \mathrm{l}$ of $2.8 \mathrm{mM} 2$-deoxy2-ribose; $20 \mathrm{mM} \mathrm{KH_{2 }} \mathrm{PO}_{4}-\mathrm{KOH}$ buffer ( $\mathrm{pH} 7.4$ ); $100 \mu \mathrm{M} \mathrm{FeCl}_{3} ; 100 \mu \mathrm{M}$ EDTA; $100 \mu \mathrm{M}$ ascorbic acid, $1 \mathrm{mM} \mathrm{H}_{2} \mathrm{O}_{2}$ and $500 \mu \mathrm{l}$ of the selected concentrations of extract $(0.1-1000 \mu \mathrm{g} / \mathrm{ml})$ to get final volume of $1 \mathrm{ml}$ and incubated at $37^{\circ}$ for $1 \mathrm{~h}$. To $0.5 \mathrm{ml}$ of the reaction mixture, $1 \mathrm{ml}$ trichloroacetic acid $(2.8 \%)$ and $1 \mathrm{ml}$ aqueous thiobarbituric acid (1\%) was added followed by incubation for $15 \mathrm{~min}$ at $90^{\circ}$. The resultant was cooled and absorbance was measured at $532 \mathrm{~nm}$ against blank. Ascorbic acid was used as a positive control. The percent radical scavenging was then calculated using Eqn. 1.

\section{Antimicrobial activity:}

The agar cup-plate method ${ }^{[19,20]}$ was employed to screen inhibitory potential of the extract against chosen microorganisms. The study included preparation of sterile Mueller-Hinton agar plates and inoculation of $100 \mu 1$ fresh inoculums by spread plate technique. Onto the prepared agar plates, cups of $8 \mathrm{~mm}$ diameter were cut and filled with $0.05 \mathrm{~m} 1$ of test and reference standard solutions. A series of 4 concentrations $(50,100,150$ and $200 \mathrm{mg} / \mathrm{ml}$ ) of the extract were used for detecting inhibitory effect in comparison to reference standards ciprofloxacin $(50 \mu \mathrm{g} / \mathrm{ml})$ and fluconazole $(0.1 \mathrm{mg} / \mathrm{ml})$ against bacteria and fungi, respectively. For effective diffusion of test and standards, all the plates were then refrigerated at $2^{\circ}$ to $8^{\circ}$ for $2 \mathrm{~h}$ followed by incubation for $24 \mathrm{~h}$ at $37^{\circ}$. The antibacterial activity was indicated by the presence of definite zones of inhibition of any size around the cup, which was measured and recorded. DMSO $(4.0 \% \mathrm{v} / \mathrm{v})$ was also run simultaneously as a control solvent. 


\section{Antiinflammatory activity:}

Antiinflammatory activity of the plant extract was evaluated using a rat model. Acute toxicity $\left(\mathrm{LD}_{50}\right)$ testing of the sample is an important prerequisite to animal experiments, which was executed by the up and down procedure ${ }^{[21]}$. After the administration of one single dose of the methanol extract $(5,50,300$, $2000 \mathrm{mg} / \mathrm{kg}$ ) the survival of animals was observed during $24 \mathrm{~h}$. If an animal survived at any given dose, the dose for the next animal was logarithmically increased; if it died, the dose was decreased.

Rats of either sex were starved overnight and grouped into five groups, normal (A), control (B), test 1 (C), test 2 (D) and standard (E). All animals were fasted for $12 \mathrm{~h}$ prior the experiment, but with access to drinking water. During the experiment their access to both feed and water was strictly restricted. Except the normal group, all the other group animals were injected with $0.05 \mathrm{ml}$ of $1 \%$ solution of carrageenan into the plantar side of the right hind paw to induce edema. After $1 \mathrm{~h}$, treatment with test extract and standard indomethacin was started on hourly basis. The detailed experimental regimen is described by fig. 1 . Width and thickness of the paws were measured by the help of a Vernier caliper (RSK, Mumbai) and paw volume (Eqn. 2) was calculated every hour ${ }^{[22]}$. Subsequently, the percent inhibition of paw edema was calculated for each group with respect to the control using Eqn. 2 and 3: paw volume $=\pi \times \mathrm{a}^{2} \times \mathrm{b}$, where, ' $a$ ' is width and ' $b$ ' is thickness of the paw; percent inhibition of edema $=1-\mathrm{V}_{\mathrm{t}} / \mathrm{V}_{\mathrm{c}} \times 100$, where; $V_{t}$, paw volume of test and $V_{c}$, paw volume of control.

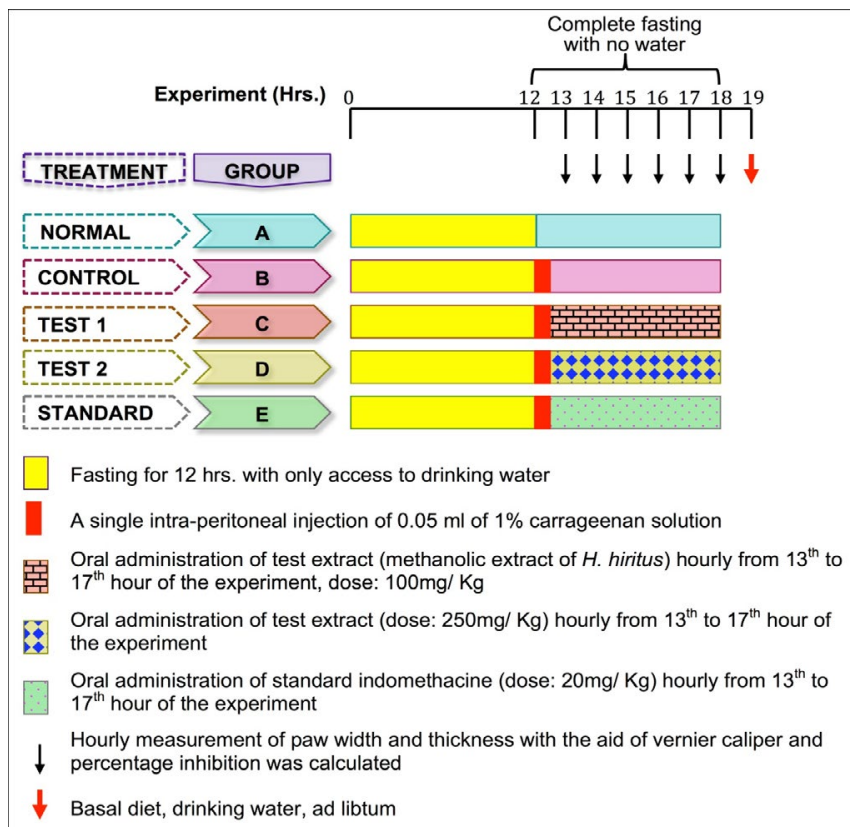

Fig. 1: Antiinflammatory study protocol
TABLE 1: MACROSCOPY OF H. HIRITUS

\begin{tabular}{|c|c|}
\hline $\begin{array}{l}\text { Morphological } \\
\text { particulars }\end{array}$ & Description \\
\hline Height & $\begin{array}{l}H . \text { hiritus is a shrub that grows up to } \\
1-1.5 \mathrm{~m} \text { high. }\end{array}$ \\
\hline Leaves & $\begin{array}{l}\text { The size of the leaves varies from 3-6 } \\
\mathrm{cm} \text { length and } 2-3 \mathrm{~cm} \text { wide. Morphology } \\
\text { observed as alternate, lower one ovate, } \\
\text { rounded or cuneate at the base, crenate- } \\
\text { serrate or irregularly toothed at the } \\
\text { margin and acute to acuminate at apex. }\end{array}$ \\
\hline Stem & $\begin{array}{l}\text { Stem is erect, pubescent with simple } \\
\text { stiff, minute stellate hairs. }\end{array}$ \\
\hline & $\begin{array}{l}\text { Flowers are axillary and solitary. Pedicel } \\
\text { is longer than the petioles and varies } \\
\text { from } 0.5 \text { to } 2 \mathrm{~cm} \text {. calyx measures } 1.5\end{array}$ \\
\hline Flowers & $\begin{array}{l}\mathrm{cm}, 5 \text { fid, linear, lanceolate and hairy. } \\
\text { Corollas (petals } 5 \text { nos.) are pink colour, } \\
\text { obovate and measures up to } 1-1.5 \mathrm{~mm} \\
\times 0.5-0.8 \mathrm{~mm} \text { rounded at the apex. }\end{array}$ \\
\hline Roots & Roots are fibrous in nature. \\
\hline Seeds & $\begin{array}{c}\text { Seeds are in locules ( } 5 \text { nos.) each } \\
\text { containing } 2-3 \text { seeds, reniform, densely } \\
\text { covered with long wooly hairs, helps in } \\
\text { wind dispersal. }\end{array}$ \\
\hline
\end{tabular}

\section{RESULTS AND DISCUSSION}

Morphological characteristics and taxonomy were studied and observations are presented in Table 1. The leaf consisted of a thick medium midrib and comparatively smaller lateral veins (fig. 2A) the midrib was thick with adaxial prominent adaxial cone and broad and thick semi-circular abaxial part. The midrib is $750 \mu \mathrm{m}$ in vertical plane used the abaxial semicircular part is $750 \mu \mathrm{m}$ in horizontal plane. The adaxial cone is $250 \mu \mathrm{m}$ height and $400 \mu \mathrm{m}$ wide. The midrib consisted of prominent circular and thin walled epidermal cells. Inner to the epidermis, there were 3 to 4 layers of collenchyma cells. Remaining portion has circular, thin walled parenchyma ground tissue, vascular strands of the midrib is plano concave with flat adaxial side and semi lunar circular abaxial side. It consisted of several narrow parallel vertical lines of xylem elements. The xylem elements were circular or angular, wide and thick walled. The protoxylem elements were directed towards adaxial side. There was a plate of sclerenchyma cells at the top of the xylem segment of phloem occurs in several small discrete units all along the convex linear part of xylem. The phloem elements were small, angular thick walled and densely stained. The vascular bundle was $250 \mu \mathrm{m}$ in horizontal plane. The lateral veins were similar to the midrib, but smaller in size. The adaxial cone, abaxial midrib and the vascular strands were all similar to the midrib. The lamina (fig. 2B) was uniform in thickness and the surfaces were smooth and even and $200 \mu \mathrm{m}$ 
in thickness. The adaxial epidermal layer consisted of rectangular wide thickened cells, the abaxial epidermal cells were small and square shaped or rectangular. There were single short compact palisade cells along the adaxial part of the lamina. The spongy parenchyma cells were 3 or 4 layered; the cells were spherical and were loosely arranged. The marginal part of the leaf (fig. 2C) was slightly dilated and measures $140 \mu \mathrm{m}$ in thickness. The epidermal cells of the marginal part were highly dilated, wide and thick walled. The mesophyll cells in the marginal and were compact without differentiation of palisade and spongy parenchyma. Small vascular strand was seen at marginal end. Stellate trichomes (fig. 2D) were sparsely seen on the lamina. The trichomes were non-glandular and covering type. It consisted of a unicellular, unbranched trichome deeply embedded in the epidermis and the aerial part of the stem.

During the paradermal study, two types of trichomes (nonglandular and glandular types) were found in the epidermal layer of both leaf and stem. The nonglandular trichomes consisted of long, thick cylindrical basal cell which was totally buried in the leaf epidermis. The outer free part of the trichome was sharply pointed at the tip. The cell wall of the trichome was thick and lignified (fig. 3A). The glandular trichomes were of capitates type with short stalk cells and dilated spherical apical secretary head (figs. 3A, B). The stalk cells were hyaline while the head cells were densely cytoplasmic. The glandular trichomes are $70 \mu \mathrm{m}$ in height, the glandular
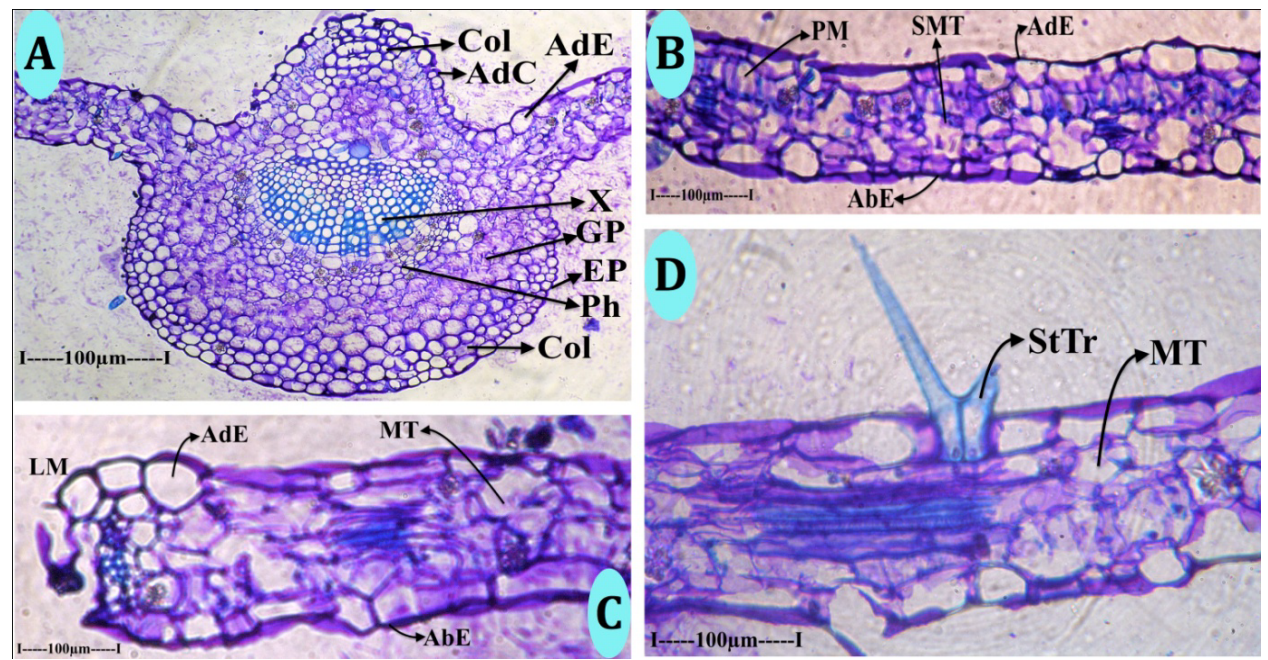

Fig. 2: Leaf microscopy

A. TS of midrib; B. TS of lamina; C. TS of leaf margin; and D. stellate non glandular trichomes. Col: collenchyma; AdE: adaxial epidermis; AbE: abaxial epidermis; AdC: adaxial cells; X: Xylem; Ph: phloem; GP: ground parenchyma; EP: epidermis; SMT: spongy mesophyll tissue; MT: mesophyll tissue; PM: palisade mesophyll; StTr: stellate trichome; LM: leaf margin
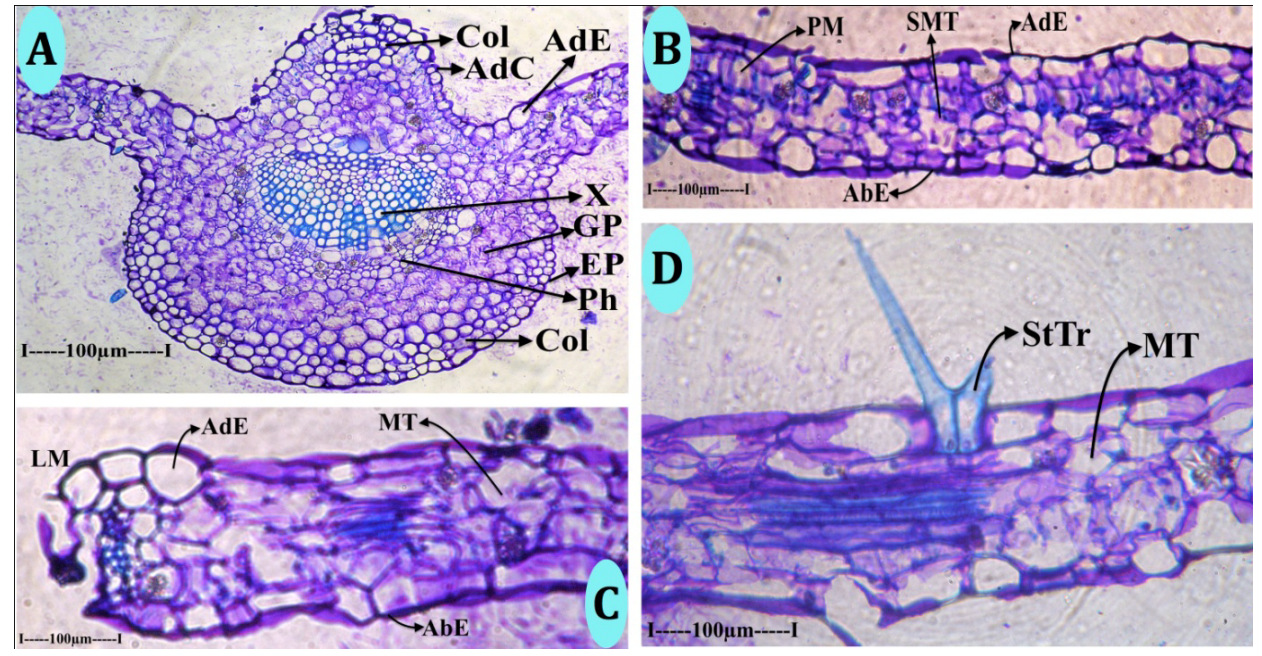

Fig. 3: Paradermal study of $\boldsymbol{H}$. hiritus

A. Leaf bearing glandular trichome, B. leaf shows non glandular and glandular trichome, C. epidermal layer with stomata, D. stoma with paracytic subsidiary cells, E. diacytic stoma, F. mucilaginous cells of the lamina. H: head; St: stoma; Ep: epidermis; GITr: glandular trichome, NGTr: non glandular trichome, Sc: subsidiary cell; SA: stomatal aperture; GC: guard cell; EC: epidermal cell; MC: mucilage cell; Mu: mucilage 
head is $40 \mu \mathrm{m}$ wide. The stomata are broadly elliptical with narrow slit line stomatal opening (figs. 3D, E); the ground cells are $70 \mu \mathrm{m}$ in vertical plane and $50 \mu \mathrm{m}$ in horizontal plane. The stomata have two subsidiary cells either arranged parallel to the guard cells (paracytic) or located at right angle to the guard cells (diacytic, fig. 3C). Mucilage secreting cells are common in leaf and stem. Some of the parenchyma cells of the ground tissue were dilated into wide circular cells, which secrete the mucilage. Mucilage turns to purple colour when stained with toluidine blue (fig. 3F).

The stem is circular in TS view, which consisted of epidermis, cortex, secondary xylem cylinder and central pith (fig. 4A). The epidermal layer consisted of uniform, small squarish thin walled cells. The cortical zone was homogeneous, parenchymatous and $160 \mu \mathrm{m}$ thick. Inner to the cortex was the secondary phloem zone, where one or two layers were dilated.
The secondary phloem consisted of small squarish thin walled cells, which arranged regular radial rows. The phloem rays were dilated into wide fan shaped outline at the peripheral part of secondary phloem (fig. 4B). There are several discrete masses of sclerenchymatous cells in the secondary phloem. The sclerenchyma cells occur in 2 successive cylinders in the phloem. The secondary phloem cylinder was $450 \mu \mathrm{m}$ thick. Secondary xylem consisted of less growing cells. The xylem included vessels, fibres and xylem rays. The vessels were solitary and diffuse in distribution. Some of the vessels were in short radial multiples (fig. 4B). The vessels were circular, wide (30-70 $\mu \mathrm{m}$ in diameter) and fairly thick walled. Xylem fibres were angular in sectional view, thick walled and lignified. The fibres occurred in compact radial lines (fig. 4A). Xylem rays are thin and cells are radially elongated and wide; they stain deeper than the fibres. The fibres are in the
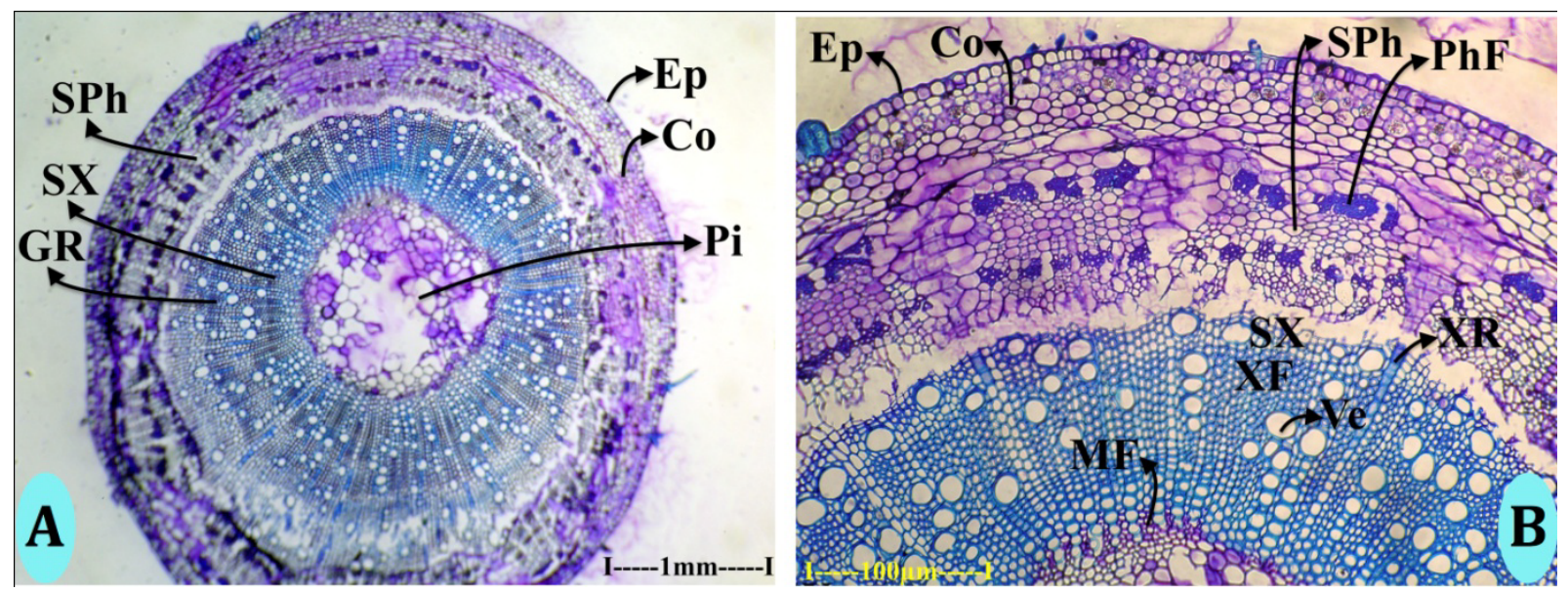

Fig. 4: TS of stem of $H$. hiritus

A. stem- entire view, B. stem- sector view. SPh: secondary phloem; SX: secondary xylem; GR: growth ring; Pi: pith; PhF: phloem fiber; XR: xylem ray; XF: xylem fiber; Ve: vessel; MF: medullary fibres
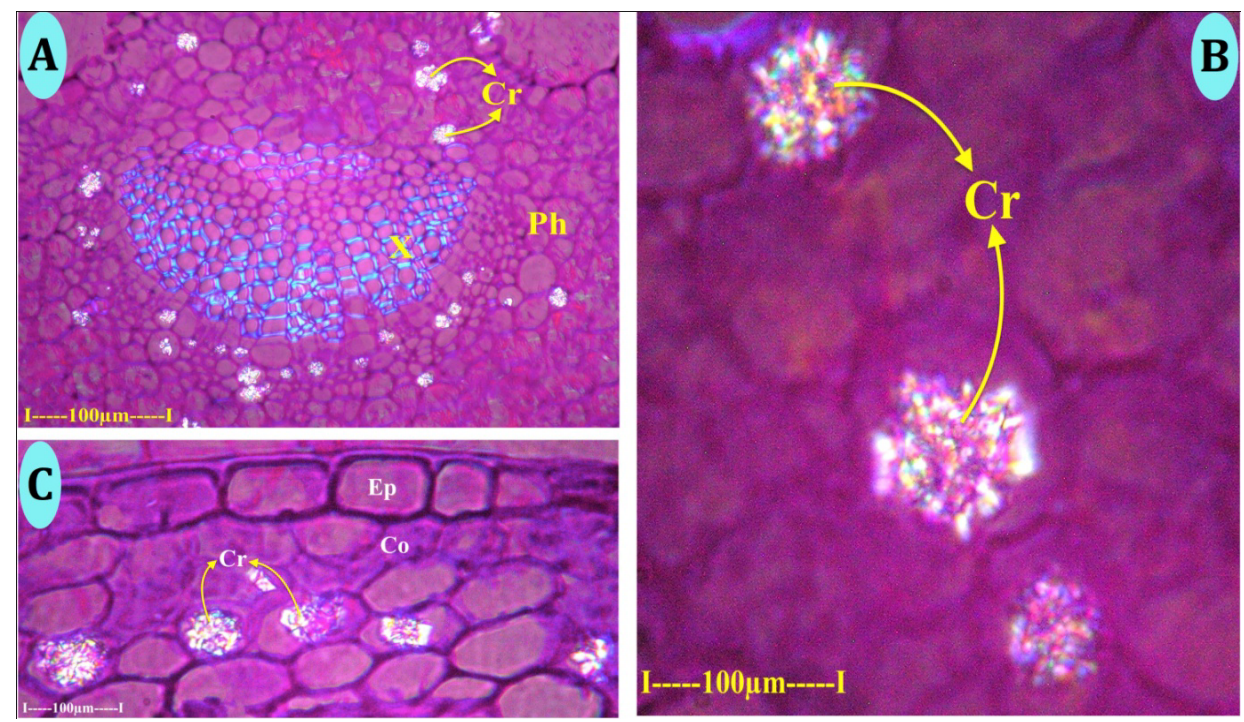

Fig. 5: Crystal distribution in stem and leaf of $\boldsymbol{H}$. hiritus A. crystals (Cr) in midrib vascular bundles; B. crystal enlarged; C. crystal distribution in the stem cortex 
inner portion, surrounding the pith have mucilaginous secondary walls and not lignified walls.

Calcium oxalate crystals (fig. 5A) are common along the abaxial zone of the midrib vascular bundle and also in other tissues of the lamina. The crystals were druses, which are spherical bodies with spiny surface (fig. 5B). The druses dispersed randomly and were solitary in the cell. The size of the crystals might vary up to $35 \mu \mathrm{m}$ in diameter. Crystals were common in cortical parenchyma cells of the stem. The crystals are druses and spherical bodies ( $20 \mu \mathrm{m}$ in diameter) with spiny surface. The druses are random in distribution and solitary in each cell (fig. 5C). The crystals appear glittered under polarized light, which is the inherent characteristic of the druses.

Successive extraction was done by hexane, chloroform and methanol to get an yield of $0.24,0.26$ and $0.36 \mathrm{~g}$ $\%$, respectively. The extracts were used for preliminary screening tests by following standard established procedures as tabulated in Table 2. From these experiments, it was observed that methanol extract was positive for most of the constituents and highest yield too. Hence, methanol was considered as the solvent of choice for the extraction of $H$. hiritus whole plant for pharmacological screening. To establish the presence of total earthy matter or inorganic composition and other impurities present along with the principal constituents, ash values (total ash, acid-insoluble ash and watersoluble ash), alcohol-soluble and water-soluble extractives were determined (Table 3). Extractive values are the quality indices for the determination of exhausted and adulterated drug ${ }^{[23]}$.
Antioxidant activity was assessed by in vitro DPPH reduction and hydroxyl radical scavenging assays using the methanol extract of $H$. hiritus. In both the methods, the antioxidant capacity of the plant extract was compared to that of ascorbic acid. The extract showing DPPH scavenging power produces a colour change from purple to yellow at $517 \mathrm{~nm}$. Fig. 6 illustrates the effect of different concentration of test extract and standard ascorbic acid on scavenging DPPH. The antioxidant capacity of the extract increased with increasing concentration. The scavenging of hydrogen peroxide by the methanol extract was determined and presented in fig. 7 in comparison to ascorbic acid. In this assay 2-deoxy-2-ribose was oxidized when exposed to hydroxyl radicals generated by Fenton-type reaction. The oxidative degradation can be detected by heating the product with TBA under acidic conditions to develop a pink chromogen (thiobarbituric acid reactive species) with a maximum absorbance at $532 \mathrm{~nm}^{[24]}$. From the result it is apparent that the hydrogen peroxide scavenging activity of the extract was concentrationdependent. At a concentration of $1 \mathrm{mg} / \mathrm{ml}$, the scavenging activity of the extract and the standard was found to be $78.54 \pm 0.5774$ and $93.62 \pm 0.23072$, respectively. Scavenging of $\mathrm{H}_{2} \mathrm{O}_{2}$ is very important for antioxidant defense in cell by various food materials like fruits, green and leafy vegetables, since it can induce oxidative damage to DNA, lipids and proteins ${ }^{[25]}$. The $\mathrm{IC}_{50}$ value of the extract was determined for DPPH and hydrogen peroxide scavenging assay and is presented in Table 4 . The $\mathrm{IC}_{50}$ values obtained for the test extract

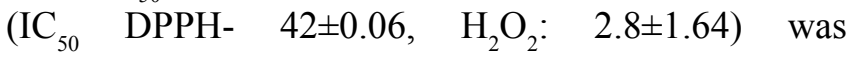

TABLE 2: PRELIMINARY PHYTOCHEMICALS SCREENING OF VARIOUS EXTRACTS

\begin{tabular}{|c|c|c|c|c|}
\hline \multirow{2}{*}{ Constituents } & \multirow{2}{*}{ Standard test } & \multicolumn{3}{|c|}{ Extraction solvent } \\
\hline & & Hexane & Chloroform & Methanol \\
\hline Steroids & Liebermann Burchard test & + & + & + \\
\hline Triterpenes & Salkowski test & + & + & + \\
\hline Saponins & Foam test & + & + & + \\
\hline Steroidal saponin & $\begin{array}{c}\text { Hydrolyzed with sulphuric acid following Liebermann } \\
\text { Burchard test }\end{array}$ & + & + & + \\
\hline Glycosides & Sodium hydroxide reagent & - & - & + \\
\hline Alkaloids & Mayer's test & - & - & - \\
\hline Carbohydrates & Benedict's test & - & - & - \\
\hline Flavonoids & Shioda test & + & + & + \\
\hline Tannins & Ferric chloride test & + & + & + \\
\hline Phenols & Lead acetate test & + & + & + \\
\hline Irioids & Trim hill reagent test & - & - & - \\
\hline Cardiac glycosides & Legal's test & - & - & - \\
\hline Mucilage & Addition of Ruthenium red & + & + & + \\
\hline Proteins & Biuret test & - & - & - \\
\hline
\end{tabular}


comparatively lower than the standard $\left(\mathrm{IC}_{50}\right.$; DPPH: $\left.12 \pm 0.05, \mathrm{H}_{2} \mathrm{O}_{2}: 1 \pm 1.18\right)$.

The antimicrobial activity of the plant extract against selected bacterial and fungal strains is presented in Table 5. The methanol extract exhibited satisfactory antibacterial potency against $S$. aureus, B. subtilis and $E$. coli with inhibition zone diameters of $14 \pm 0.15$, $14 \pm 0.13$ and $14 \pm 0.16 \mathrm{~mm}$, respectively. Lesser

TABLE 3: PERCENT ASH AND EXTRACTIVE VALUES OF $H$. HIRITUS

\begin{tabular}{lc}
\hline Parameters & $\boldsymbol{H}$. hiritus $(\% \mathrm{w} / \mathrm{W} \pm$ SD) \\
\hline Total ash & $7.25 \pm 0.63$ \\
Acid insoluble ash & $0.23 \pm 0.04$ \\
Water soluble ash & $0.3 \pm 0.43$ \\
Alcohol soluble extractives & $18.53 \pm 0.33$ \\
Water soluble extract & $19.63 \pm 0.48$ \\
\hline
\end{tabular}

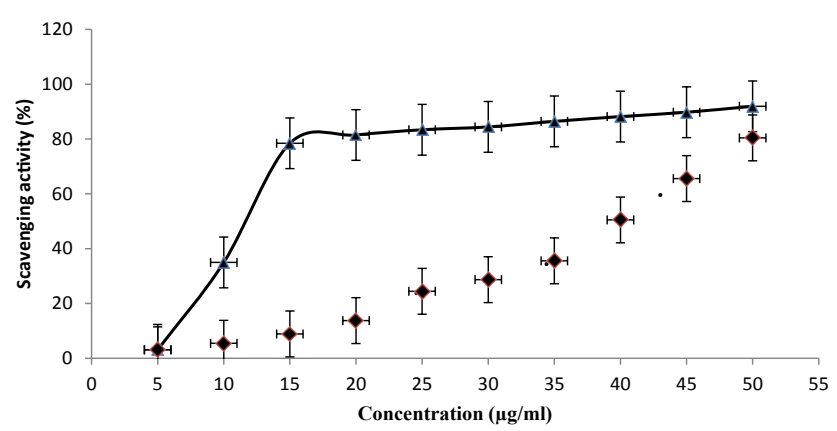

Fig. 6: DPPH radical scavenging by methanol extract $H$. hiritus extract and ascorbic acid

DPPH radical scavenging activities of various concentrations of $H$. hiritus methanol extract (-- $\Delta--)$ and ascorbic acid (-४)). *Values are expressed as mean \pm SD percent inhibition

TABLE 4: IC 50 VALUE OF IN VITRO ANTIOXIDANT ACTIVITIES OF H. HIRITUS

\begin{tabular}{lcc}
\hline Sample & $\begin{array}{c}\text { DPPH radical } \\
\text { scavenging } \\
\text { activity }\end{array}$ & $\begin{array}{c}\text { Hydroxyl radical } \\
\text { scavenging } \\
\text { activity }\end{array}$ \\
\hline$H$. hiritus $(\mu \mathrm{g} / \mathrm{ml})$ & $42 \pm 0.06$ & $2.8 \pm 1.64$ \\
Ascorbic acid $(\mu \mathrm{g} / \mathrm{ml})$ & $12 \pm 0.05$ & $1 \pm 1.18$ \\
\hline
\end{tabular}

Values expressed as mean $\pm S D$ inhibitory activity was observed against $P$. vulgaris $(12 \pm 0.14 \mathrm{~mm})$, A. niger $(12 \pm 0.07 \mathrm{~mm})$ and C. albicans $(12 \pm 0.05 \mathrm{~mm})$ even at higher concentration of the extract.

The observed in vivo antiinflammatory activity in the rat paw edema experiment was highly potent and closer to that of standard indomethacin. The percent inhibition of paw volume ranging from $58.97 \pm 0.67$ to 71.73 $\pm 0.45 \%$ for different animal groups at different time interval is illustrated in Table 6. However, the exact mechanism of antiinflammatory action is out of the scope of our study.

The present investigation confirmed the effectiveness of $H$. hiritus as a bacteriostatic, antioxidant and antiinflammatory agent, which is extensively used in traditional medicine. To the best of our knowledge, this is the first report on the evaluation of pharmacognostic characteristics and pharmacological activities of this endangered, monotypic plant. The pharmacognostic profile of the leaves, stem and paradermal studies demonstrated the special features of the plant that

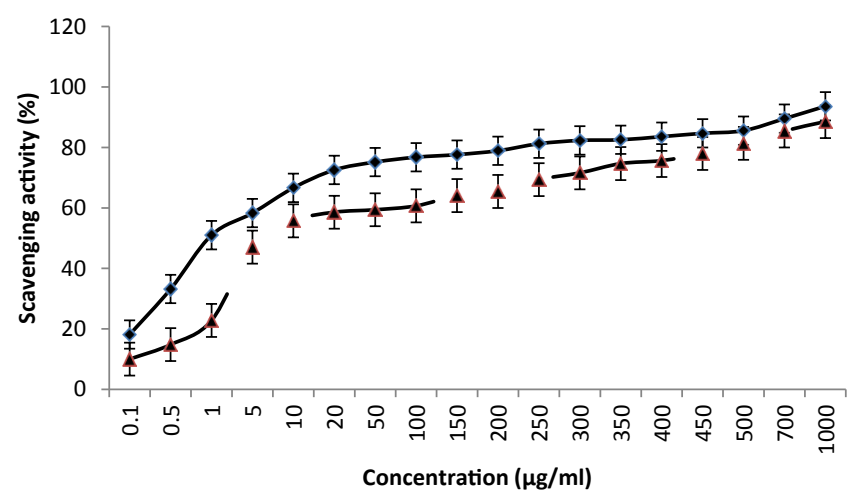

Fig. 7: Inhibition of hydroxyl radicals by methanol extract of $H$. hiritus and ascorbic acid

Percent inhibition of hydroxyl radicals by treating with various concentrations of methanol extract of $H$. hiritus (-- $\Delta--)$ and standard ascorbic acid (—^). *Percent inhibition values are expressed as mean \pm SD

TABLE 5: ZONES OF INHIBITION OF MICROBIAL GROWTH BY METHANOL EXTRACT OF H. HIRITUS

\begin{tabular}{lccccc}
\hline Name of the organism & \multicolumn{5}{c}{ Zones of growth inhibition $(\mathrm{mm})$} \\
\cline { 2 - 6 } $\begin{array}{l}\text { S. } \text { aureus } \\
\text { (Gram + ve) }\end{array}$ & Standard & $\mathrm{T}_{1}$ & $\mathrm{~T}_{2}$ & $\mathrm{~T}_{3}$ & $\mathrm{~T}_{4}$ \\
$\begin{array}{l}\text { B. subtilis } \\
\text { (Gram +ve) }\end{array}$ & $24 \pm 0.11$ & $11 \pm 0.12$ & $12 \pm 0.15$ & $13 \pm 0.12$ & $14 \pm 0.15$ \\
$\begin{array}{l}\text { P. vulgaris } \\
\text { (Gram -ve) }\end{array}$ & $25 \pm 0.23$ & $11 \pm 0.13$ & $12 \pm 0.15$ & $13 \pm 0.22$ & $14 \pm 0.13$ \\
$\begin{array}{l}\text { E. coli } \\
\text { (Gram -ve) }\end{array}$ & $24 \pm 0.12$ & $11 \pm 0.12$ & $12 \pm 0.16$ & $12 \pm 0.23$ & $12 \pm 0.14$ \\
$\begin{array}{l}\text { A. niger } \\
\text { C. albicans }\end{array}$ & $25 \pm 0.22$ & $11 \pm 0.11$ & $12 \pm 0.14$ & $12 \pm 0.16$ & $14 \pm 0.16$ \\
\hline
\end{tabular}

Zones of inhibition were measured in $\mathrm{mm}$. Well diameter is $8.00 \mathrm{~mm}$, standard $50 \mu \mathrm{g} / \mathrm{ml}$ ciprofloxacin, $\mathrm{T}_{1}-\mathrm{T}_{4}: 50,100,150$ and $200 \mathrm{mg} / \mathrm{ml}$ of test extract. *Values obtained in triplicate and data expressed as mean \pm SD. 
TABLE 6: ANTIINFLAMMATORY ACTIVITY OF H. HIRITUS IN CARRAGEENAN-INDUCED RAT PAW EDEMA MODEL

\begin{tabular}{lccccccc}
\hline \multirow{2}{*}{ Group } & Dose & \multicolumn{7}{c}{ \% Inhibition of paw volume } \\
\cline { 3 - 8 } & $(\mathrm{mg} / \mathrm{kg})$ & $1 \mathrm{~h}$ & $2 \mathrm{~h}$ & $3 \mathrm{~h}$ & $4 \mathrm{~h}$ & $5 \mathrm{~h}$ & $6 \mathrm{~h}$ \\
Control & $-\mathrm{--}$ & 0 & 0 & 0 & 0 & 0 & 0 \\
Standard $^{*}$ & 20 & $25.31 \pm 0.47$ & $42.90 \pm 0.45$ & $57.5 \pm 0.45$ & $61.95 \pm 0.44$ & $71.74 \pm 0.45$ & $72.35 \pm 0.45$ \\
Test 1 $^{*}$ & 100 & $20.64 \pm 0.11$ & $37.50 \pm 0.17$ & $39.04 \pm 0.46$ & $40.56 \pm 0.67$ & $49.57 \pm 0.44$ & $58.97 \pm 0.67$ \\
Test 2 $^{*}$ & 250 & $25.30 \pm 0.14$ & $40.58 \pm 0.11$ & $55.27 \pm 0.19$ & $55.64 \pm 0.29$ & $62.04 \pm 0.12$ & $71.73 \pm 0.45$ \\
\hline
\end{tabular}

*Values obtained in triplicate and data expressed as mean \pm SD

would help develop quality control standards. The methanol extract of the plant exhibited antioxidant and antiinflammatory activity under the experimental conditions. From the antimicrobial study, moderate bacteriostatic and poor fungicidal activity was observed. Nevertheless, the possibility that the extract could be an effective antimicrobial agent cannot be ruled out since the plant extract used in this study might not contain the compounds responsible for this activity in adequate concentrations. In addition, an optimal extraction condition for specific activity is highly recommended for more satisfactory results. Thus, these results provided a scientific basis for further studies on quality control, activity-based optimization and clinical trials to realize the therapeutic potential of this plant.

\section{Acknowledgements:}

The authors wish to thank the Management and Principal of Raghu College of pharmacy, Visakhapatnam for their constant support and providing necessary facilities for the smooth conduct of the study. Authors also thank PARC (Plant Anatomical Research Centre), Chennai for providing laboratory facilities to complete microscopic studies. Authors acknowledge Mr. L. Rasingam, Scientist In-charge, Botanical Survey of India, Hyderabad, Telangana for identifying and authenticating the plant material.

\section{REFERENCES}

1. Perumal SR, Ignacimuthu S. Antibacterial activity of some folklore medicinal plants used by tribals in Western Ghats of India. J Ethnopharmacol 2000;69:63-71.

2. Gong H, Li S, He L, Kasimu R. Microscopic identification and in vitro activity of Agastacherugosa (Fisch. etMey) from Xinjiang, China. BMC Complement Altern Med 2017;17:95.

3. Zaidan MR, Noor Rain A, Badrul AR, Adlin A, Norazah A, Zakiah I. In vitro screening of five local medicinal plants for antibacterial activity using disc diffusion method. Trop Biomed 2005;22(2):165-70.

4. Deepshikha, Amit KR. Swarnaprashan - Classical review \& Current scenario. World J Pharm Res 2014;3(7):298-304.

5. Evans WC, Evans D, Trease GE. Trease and Evan's Pharmacognosy. 16th ed. Philadelphia, Pennsylvania, United States: Saunders; 2009.
6. Sass JE. Elements of Botanical Microtechnique. New York: McGraw Hill Book Co; 1940. p. 222.

7. Johansen DA. Plant Microtechnique. New York: McGraw Hill 1940. p. 182-203, 523.

8. O'Brien TP, Feder N, Mc Cull ME. Polychromatic Staining of Plant Cell walls by toluidine blue-O. Protoplasma 1964;59:364-373.

9. Easu K. Anatomy of seed Plants. New York: John Wiley and Sons; 1979. p. 550.

10. Easu K. Plant Anatomy. New York: John Wiley and Sons; 1964. p.767.

11. Kay AL. The microscopic study of drugs. London: Bailliere Tindall and Cox; 1938. p. 16-21.

12. Anonymous. Indian Pharmacopoeia. 2nd ed. Ghaziabad, Uttar Pradesh, India: Indian Pharmacopoeia Commission, Government of India; 1966.

13. Chandrashekhar T, Anju G. Antioxidant Activity by DPPH Radical Scavenging Method of Ageratum conyzoides Linn. Leaves. Am J Ethnomed 2014;4:244-9.

14. Kulisic T, Radonic A, Katalinic V, Milos M. Use of different methods for testing antioxidative activity of oregano essential oil. Food Chem 2004;85:633-40.

15. Kriengsak T, Unaroj B, Kevin C, Luis CZ, David HB. Comparison of ABTS, DPPH, FRAP, and ORAC assays for estimating antioxidant activity from guava fruit extracts. J Food Composition Anal 2006;19:669-75.

16. Ilhami GL, Zubeyr H, Mahfuz E, Hassan Y, Enein A. Radical scavenging and antioxidant activity of tannic acid. Arab J Chem 2006;3:43-53.

17. Saumya SM, Mahaboob BP. In vitro Evaluation of Free radical scavenging activities of Panax ginseng and Lagerstroemia speciosa: a comparative analysis. Int $\mathrm{J}$ Pharm Pharm Sci 2011;3:165-9.

18. Anuj M, Ashok K, Vipin S, Sarita S, Sharad K, Yogesh CY. In vitro antioxidant properties of Scopoletin. J Chem Pharm Res 2011;3(3):659-65.

19. Gouri KD, Suresh P, Sahu SK, Kar DM, Ganapaty S, Panda SB. Evaluation of Evolvulu salsinoides Linn. for Anthelmintic and Antimicrobial activities. J Nat Remedies 2002;2/2:182-5.

20. Bibi SFB, Mehrangiz K, Hamid RS. In vitro Antibacterial Activity of Rheum ribes Extract Obtained from Various Plant Parts Against Clinical Isolates of Gram-Negative Pathogens, Iran J Pharm Res 2005;2:87-91.

21. Turner RA. Screening methods in pharmacology. New York: Academic Press; 1965.

22. Mukesh G, Tejal S, Lal H, Asha P, Nayan P. Development and Optimization of Plant Extract Loaded Nanoemulsion Mixtures for the Treatment of Inflammatory Disorder. Curr Res Drug Discovery 2014;1(2):29-38.

23. von Unruh GE, Voss S, Sauerbruch T, Hesse A. Dependence of Oxalate absorption on the daily calcium intake. J Am Soc Nephrol 2004;15:1567-73. 
24. Cheng Z, Li Y, Chang W. Kinetic deoxyribose degradation assay and its application in assessing the antioxidant activities of Phenolic compounds in a Fenton-type reaction system. Anal Chim Acta 2003;478:129-37.
25. Spencer JPE, Jenner A. Aroma of Intense oxidative DNA damage promoted by L-DOPA and its metabolites, implications for neurodegenerative disease. Federation Eur Biochem Soc Lett 1994;353:246-50. 